\title{
Validation of diabetes knowledge questionnaire in Croatian with assessment of diabetes knowledge and quality of life in patients with type 2 diabetes mellitus
}

\section{ABSTRACT}

Background. Diabetes mellitus (DM) is one of the biggest challenges in global healthcare and society in general. Assessment of the patient's level of knowledge regarding diabetes is an important step in adapting group education programs to achieve better treatment outcomes.

The aim of this study was to validate Diabetes Knowledge Questionnaire (DKQ) in Croatian language, to evaluate knowledge about diabetes and examine the relationship between knowledge and quality of life among type 2 DM patient's in Croatia.

Methods. The study was conducted as a cross-sectional study on $\mathbf{5 0 0}$ subjects. Validation of DKQ questionnaire in Croatian language was done using forward-backward method and internal consistency was examined using Cronbach's Alpha. Quality of life was assessed using WHOQOL-BREF Questionnaire.

Results. Good reliability and internal consistency of DKQ was confirmed $(\alpha=0,740)$. Overall knowledge about diabetes was satisfactory (average DKQ score was 12,13$)$. Longer duration of disease and previous education about diabetes were observed as predictive factors of better knowledge. No association was found between diabetes knowledge and quality of life.

Address for correspondence:

Miroslav Ćaćić

Wassermannstraße 73, 12489 Berlin

Phone: +49151262 99352

e-mail: mefmir@gmail.com

Clinical Diabetology 2020, 9; 6: 387-393

DOI: $10.5603 /$ DK.2020.0054

Received: 08.06.2020

Accepted: 02.11.2020
Conclusions. Our study confirms that DKQ is a good tool for assessing diabetes knowledge in Croatian language. Patients with DM demonstrated good diabetes knowledge but education in areas of self-care and nutrition needs to be improved which may increase quality of life. (Clin Diabetol 2020; 9; 6: 387-393)

Key words: diabetes mellitus, quality of life, knowledge, DKQ, WHOQOL-BREF

\section{Introduction}

Diabetes mellitus (DM) is one of the biggest challenges in global healthcare and society in general. As reported by the International Diabetes Federation over 463 million people worldwide are living with diabetes. It is the world's leading cause of blindness, kidney failure, heart attack, stroke and lower extremity amputation [1]. Additional concern is the rapid increase of the prevalence in both middle and low gross national income countries, where most of the world's population lives, including Croatia [2]. DM is a large-scale health, social and economic burden with huge effect on personal satisfaction and life expectancy [3, 4]. Patients with type 2 diabetes often die from heart attacks, sudden cardiac death and strokes [5-8]. Therefore, the goal of diabetes therapy is to minimize and delay the occurrence of diabetic complications and to improve the quality of life (QOL) of those affected.

Diabetes care is based on an individualized approach, which takes into consideration the needs and circumstances of the adults with type 2 diabetes. Diabetes management plan includes structured education, dietary advice, advice on other aspects of lifestyle modification (such as increasing physical activity and 
losing weight) and drug treatment for blood glucose control.

Assessment of the patient's level of knowledge regarding diabetes is an important step in adapting group education programs to achieve better treatment outcomes. Knowledge is possible to evaluate by using different instruments like the Diabetes Knowledge Questionnaire (DKQ) [9] which was chosen for this study due to the proven correlation between diabetes knowledge and glycemic parameters $[10,11]$. In the Republic of Croatia there is no questionnaire to assess a patient's level of knowledge about diabetes.

Quality of life is individual's subjective perception on the impact of the disease on physical health, psychological state, social relationship, environment and general well-being [12]. The studies show that QOL, for people living with chronic disease such as DM, which requires complex management and coping with diabetic complications, is decreased, compared to healthy individuals [13]. Based on clinical experience, we assumed that satisfactory knowledge about DM is a good way toward achieving good glycemic control and reducing diabetes-related complications which can have a positive impact on patients' QOL.

Therefore, the study has three objectives: (1) to validate DKQ [9] (Appendix 1) in Croatian language; (2) to identify knowledge about diabetes and (3) to study the relationship between knowledge and quality of life among type 2 diabetes mellitus patients in Croatia.

\section{Methods}

The study was conducted as a cross-sectional study on subjects with type 2 diabetes which were over 18 of age, had met criteria for the diagnosis of type 2 diabetes mellitus according to WHO guidelines (fasting plasma glucose concentration $\geq 7 \mathrm{mmol} / \mathrm{L}$ or plasma glucose concentration 2 hours after glucose loading $[\geq 11.1 \mathrm{mmol} / \mathrm{L}])$, their antidiabetic therapy was not modified at least 3 months before joining the research and they declared themselves willing to participate in the research.

Subjects with serious mental disorders (psychotic and bipolar affective disorder) and/or Alzheimer's disease were excluded from this research.

A total number of 500 patients were included in this study. The research was conducted in accordance with the principles of the Declaration of Helsinki with approval of relevant Ethics Committees.

Written informed consent was obtained from all the participants prior to the start of the study.

DKQ is an instrument originally developed for native English speakers in a form of 60-item questionnaire.
Standard reduced version, used in our study, contains 24 questions with three response options "yes", "no" and "I don 't know". Prior to the usage of questionnaires in other languages and cultures, it is necessary to carry out an intercultural adaptation process. "Exclusive translation, without regard to cultural differences, results in systematic bias" $[14,15]$.

In the first part of the research, intercultural adaptation and linguistic adaptation was conducted using forward-backward technique.

Three diabetology specialists, who are excellent speakers of English language, have independently translated the original form from English to Croatian. A consensus was found between the versions that would best suit the Croatian language, all with final approval of a university professor who is also a specialist in endocrinology and diabetology. A diabetology physician who is a native speaker of English and Croatian did a backward translation of the Croatian version into English, which showed that translation did not differ from the original English version. Lastly, the final version (Appendix 2) was reviewed and approved by an expert panel consisting of diabetology specialists.

Qualified physicians first introduced DKQ to participants, who completed the questionnaire independently. For all questions and uncertainties qualified medical staff (including diabetologist, family physician or qualified nurses) was at disposal.

One point was given for each correct answer. For incorrect answers no points were taken away, nor negative points were assigned. A total of 24 points could be achieved and $>12$ accurately recognized statements defined satisfactory knowledge. Individual scores for each participant were calculated.

Quality of life was measured using WHO Quality of Life-BREF (WHOQOL-BREF) questionnaire that comprises 26 items which measure following 4 domains: physical health, psychological health, social relationships and environment (domains 1-4, respectively) [12]. The responses followed a Likert scale [16] from 1 to 5 where higher score indicates better quality.

Participant's background characteristics and laboratory test results were obtained from medical records, while demographic information such as gender, age, level of education, marital and employment status was filled in by patients themselves.

Statistical evaluation of the data was carried out using SPSS statistical package, version 26.0 for Windows. The variables were reported using descriptive statistics, with decimal numbers and percentages. Internal consistency of DKQ was assessed with Cronbach's Alpha. A multiple regression analysis and Pearson's correlation coefficient were run to determine variables associated 
with good knowledge of diabetes where $\mathrm{P}<0.05$ was considered as significant.

\section{Results}

A total of 500 subjects was included in this study, where $50.9 \%$ were men, $76.6 \%$ were married, $44.7 \%$ had high school graduation, and $39.3 \%$ were employed (Table 1). $70.11 \%$ were being treated by family physicians only, and $29.9 \%$ by diabetologist. Almost half of the participants were enrolled in one of the educational programs on symptoms, self-care and treatment of diabetes, out of which $55 \%$ was in the individual programs, and the rest in the group program. When asked about willingness for future participation in education, $58.1 \%$ of subjects responded positively and $30.1 \%$ would prefer group programs. Data regarding diabetes complication were obtained from participant's medical records as follows: $39 \%$ of subjects had neuropathy, $18 \%$ retinopathy and $29 \%$ nephropathy. $18 \%$ had previously suffered from heart attack, $7 \%$ had experienced at least 1 stroke and $17 \%$ were diagnosed with peripheral artery disease.

DKQ was successfully translated into Croatian language using forward-backward technique. The participants presented a good understanding of all items, thus no questions were modified. Good internal consistency of the questionnaire was demonstrated (Cronbach's Alpha $[\alpha=0.740]$ ).

Overall mean score of DKQ was 12.13 ( \pm 4.75$)$ indicating good knowledge. Specifically, $79.8 \%$ of examinees did not know that blood sugar level of 210 in a fasting glucose test is very high, and $78.5 \%$ that if untreated, the amount of blood sugar usually rises. $75.5 \%$ did not know that a usual cause of diabetes is lack of effective insulin in the body. Furthermore, 79.4\% did not know diabetics should take extra care when cutting toenails, $68.7 \%$ that cuts and abrasions on diabetics heal more slowly, and the same percentage did not know that diabetes can damage kidneys. Moreover, $53 \%$ knew that a person with diabetes should clean a wound with an iodine solution and alcohol, 51.9\% knew that diabetic diet does not consist of special foods and $44.7 \%$ knew that eating too much sugar and sweet foods do not cause diabetes.

A multiple regression was run to predict DKQ score from different variables of study participants. The model statistically significantly predicted DKQ score $F$ $(7,491)=25.279, P<0.0000, R^{2}=0.265$. Variables such as diabetes disease duration $(P=0.004)$, participant's previous enrollment in education about diabetes $(P=0.012)$ and treatment of disease by diabetologist versus family physician $(P=0.000)$ added statistically significantly to the prediction of DKQ score. The high-
Table 1. Population charateristics

\begin{tabular}{|c|c|c|}
\hline Subjects characteristics & \multicolumn{2}{|l|}{ n (\%) } \\
\hline \multicolumn{3}{|l|}{ Sex } \\
\hline Male & \multicolumn{2}{|l|}{$254(50.9)$} \\
\hline Female & \multicolumn{2}{|l|}{$245(49.1)$} \\
\hline \multicolumn{3}{|l|}{ Educational level } \\
\hline Unfinished primary school & \multicolumn{2}{|l|}{$24(5)$} \\
\hline Primary school & \multicolumn{2}{|l|}{$71(14.8)$} \\
\hline High school & \multicolumn{2}{|l|}{$223(46.4)$} \\
\hline $\mathrm{BA} / \mathrm{BSC}$ or $\mathrm{MS} / \mathrm{MSc}$ degree & \multicolumn{2}{|l|}{$163(33.9)$} \\
\hline \multicolumn{3}{|l|}{ Working status } \\
\hline Employee & \multicolumn{2}{|l|}{$196(40.2)$} \\
\hline Self employed & \multicolumn{2}{|l|}{$16(3.3)$} \\
\hline Retired & \multicolumn{2}{|l|}{$196(40.2)$} \\
\hline Unemployed & \multicolumn{2}{|l|}{$78(16)$} \\
\hline Miscellaneous & \multicolumn{2}{|l|}{$1(0.2)$} \\
\hline \multicolumn{3}{|l|}{ Marital status } \\
\hline Married & \multicolumn{2}{|l|}{$382(78.6)$} \\
\hline In a partnership & \multicolumn{2}{|l|}{$16(3.3)$} \\
\hline Widow/er & \multicolumn{2}{|l|}{$40(8.2)$} \\
\hline Divorced & \multicolumn{2}{|l|}{$30(6.2)$} \\
\hline Never married & \multicolumn{2}{|l|}{$18(3.7)$} \\
\hline & Mean (min-max) & SD \\
\hline Age & $62.13(35-90)$ & \pm 10.15 \\
\hline Duration of diabetes (years) & $9.64(0.1-40)$ & \pm 7.92 \\
\hline BMI & $27.00(13.67-36.2)$ & \pm 2.24 \\
\hline $\mathrm{HbA}_{1 \mathrm{c}}$ & $7.57(5.2-14.4)$ & \pm 1.01 \\
\hline Overall satisfaction with life & $7.69(1-10)$ & \pm 1.77 \\
\hline DKQ correct answers & $12.13(1-23)$ & \pm 4.75 \\
\hline
\end{tabular}

est contributing predictor is the patient's participation in education about diabetes (.933). Higher DKQ score was detected in patients who were involved in the group programs in comparison to individual programs, however the difference was not statistically significant. Age, gender, $\mathrm{BMI}, \mathrm{HbA}_{1 \mathrm{c}}$ or educational background was not recognized as factors associated with good knowledge about diabetes.

Average WHOQOL-BREF score was 24.43, 22.18, 11.1 and 31.84 for domains $1-4$, respectively. 33,5\% subjects declared they were extremely satisfied with their life (8/10) (Likert scale where 1 signifies completely dissatisfied and 10 completely satisfied).

\section{Discussion}

One of the objectives of this study is to validate DKQ questionnaire in Croatian language. Good reliability and internal consistency was confirmed using Cronbach's Alpha $(\alpha=0.740)$. Compared to other studies with DKQ questionnaire, $\alpha$ is lower than in the study done in Portugal [17] and Mexico [18], but higher 
than Nepal [19] and India [20]. The overall mean of correct answer was 12.13 which indicates good diabetes knowledge among our participants.

Despite good overall knowledge, questions with the low score raised several concerns. The lowest level of knowledge was related to identifying the fasting blood sugar level of 210 is too high. As self-measurement of blood glucose is recognized as one of the main factors in decreasing diabetes-related morbidity and mortality [21], blood glucose monitor is assigned to every patient diagnosed with type 2 diabetes in Croatia. Physicians are able to choose and recommend one, among more than 25 different glucose monitors currently available on the Croatian market [22], each of with slightly different settings. One of the explanations can be that using more sophisticated glucose monitors reduce the need of memorizing numbers itself, because of their possibility to perform software-based analysis and alarm when the glucose levels are too high. However, giving the age and education background of the participants, the main concern is whether the self-measurement of glucose level is conducted at all. In addition, we found that the majority of participants do not recognize signs of hyperglycemia (61.4\%) and hypoglycemia (69\%). These findings only highlight the need for constant education and raising the consciousness about potential signs, which could be a risk for a patient's life. Our result was expected from the similar previous studies $[18,20,23]$.

Around $50 \%$ of patients thought that diabetic diet consists mainly of special foods, two thirds did not know regular exercise can have influence on need for insulin or other diabetic medication, one third of patients knew that kidneys do not produce insulin and around the same percentage knew about 2 main types of diabetes [11].

Study conducted in Mexico shows that their patients have very high awareness of cutting their toenails with care and about damage diabetes could cause to their kidneys [18], which is in high contrast to our study. A possible explanation might be that Croatian citizens respond poorly to programs for prevention or early detection of disease and are more likely to spend money on alcoholic beverages and tobacco rather than health service. In addition, health literacy and self-care awareness are lower than in the rest of European Union [24].

The most important predictors of the total knowledge scores are previous education about diabetes $(P=0.012)$ followed by duration of disease $(P=0.004)$. Similar findings were confirmed in other studies [25-27], suggesting that patients are able more effectively adapt to diabetes treatment when having appropriate education. Moreover, the duration of disease increases the knowledge due to expanded experience and the awareness of self-care. No significant correlation was detected between knowledge and age, which was confirmed by similar study [27] suggesting that patients of all ages are eligible for educational program.

In the study about the determinants of diabetes knowledge [23], lower education was observed as risk factor. Similarly, participants in our study without any education had lower DKQ results in comparison to those with higher education although statistical significance was not achieved.

In contrast to our assumption but in line with similar studies $[18,25,26], \mathrm{HbA}_{1 \mathrm{c}}$ was not recognized as a factor influenced by total knowledge score $(P=0.387)$.

To the best of our knowledge, this is the first time to assess the level of diabetes knowledge for people in southeastern Europe, and first time to explore correlation between knowledge and quality of life using DKQ and WHOQOL-BREF, respectively.

As in other studies [28], our participants expressed high satisfaction with their quality of life in areas of physical, psychological and environmental health. On the other side, average score in the domain of social health, which concerns personal relationships, social support and sexual activity, is lower. This was expected because of lower number of questions in comparison with other domains but also the conservative upbringing and values which are still of great influence in Croatia.

Our study demonstrates that diabetic knowledge does not correlate with quality of life, which is in accordance with similar study [29]. It can be partially explained by the complex nature of the disease itself and other independent factors such as education, level of income, but also social and cultural circumstances, which highly influence people's quality of life.

Limitations of our study concerns participant's residence, which is mostly concentrated on the area of the capital city Zagreb and closer surroundings while the inclusion of more people from other parts of the country may result in different findings and accurately reflect the general population. Furthermore, involvement in the study was voluntary and it is more likely for patients with higher levels of disease awareness to be willing to participate.

Our findings reveal that DKQ is a good tool for assessing diabetic knowledge in Croatian language but also underline the need for more comprehensive initiatives targeting diabetics knowledge, especially recognizing symptoms of hypo/hyperglycemia and emphasizing exercise which can highly determine adherence to medications and improve target goals. 


\section{Conclusions}

The study demonstrated good internal consistency of DKQ and as such is a reliable instrument for measuring diabetes knowledge, applicable for further studies in Croatian language. Even though Croatian diabetics have good overall knowledge about disease, improvement is especially necessary in the areas such as selfcare and nutrition. We did not find a positive correlation between diabetes knowledge and quality of life. Still, we believe it would be interesting to conduct studies in other countries with different health care systems and cultures to more precisely explore this correlation.

\section{Conflicts of interest}

The authors have no conflict of interest to report.

\section{REFERENCE}

1. International Diabetes Federation. IDF DIABETES ATLAS 9th edition 2019 . https://www.diabetesatlas.org/ (1.05.2020).

2. Dunachie S, Chamnan P. The double burden of diabetes and global infection in low and middle-income countries. Trans R Soc Trop Med Hyg. 2019; 113(2): 56-64, doi: 10.1093/trstmh/try124, indexed in Pubmed: 30517697.

3. Bommer C, Sagalova V, Heesemann E, et al. Global Economic Burden of Diabetes in Adults: Projections From 2015 to 2030. Diabetes Care. 2018; 41(5): 963-970, doi: 10.2337/dc17-1962, indexed in Pubmed: 29475843.

4. Preston SH, Choi D, Elo IT, et al. Effect of Diabetes on Life Expectancy in the United States by Race and Ethnicity. Biodemography Soc Biol. 2018; 64(2): 139-151, doi: 10.1080/19485565.2018.1542291, indexed in Pubmed: 31178981.

5. Aune D, Schlesinger S, Norat $T$, et al. Diabetes mellitus and the risk of sudden cardiac death: A systematic review and metaanalysis of prospective studies. Nutr Metab Cardiovasc Dis. 2018; 28(6): 543-556, doi: 10.1016/j.numecd.2018.02.011, indexed in Pubmed: 29730085.

6. Chen R, Ovbiagele B, Feng W. Diabetes and Stroke: Epidemiology, Pathophysiology, Pharmaceuticals and Outcomes. Am J Med Sci. 2016; 351(4): 380-386, doi: 10.1016/j.amjms.2016.01.011, indexed in Pubmed: 27079344.

7. Li W, Li M, Gao C, et al. Impact of type 2 diabetes mellitus on recurrent myocardial infarction in China. Diab Vasc Dis Res. 2016; 13(6): 395-404, doi: 10.1177/1479164116653606, indexed in Pubmed: 27390227.

8. Israel CW, Lee-Barkey YH. Sudden cardiac death in diabetes mellitus. Herz. 2016; 41(3): 193-200, doi: 10.1007/s00059-0164421-9, indexed in Pubmed: 27071967.

9. Garcia AA, Villagomez ET, Brown SA, et al. The Starr County Diabetes Education Study: development of the Spanish-language diabetes knowledge questionnaire. Diabetes Care. 2001; 24(1): 16-21, doi: 10.2337/diacare.24.1.16, indexed in Pubmed: 11194219.

10. Dawson AZ, Walker RJ, Egede LE. Differential Relationships Between Diabetes Knowledge Scales and Diabetes Outcomes. Diabetes Educ. 2017; 43(4): 360-366, doi: 10.1177/0145721717713316, indexed in Pubmed: 28595504.

11. Bukhsh A, Lee SW, Pusparajah P, et al. Psychometric Properties of the Urdu Version of Diabetes Knowledge Questionnaire. Front
Public Health. 2017; 5: 139, doi: 10.3389/fpubh.2017.00139, indexed in Pubmed: 28702453.

12. The World Health Organization. https://www.who.int/substance_ abuse/research_tools/whoqolbref/en/ (1.05.2020).

13. Tavakkoli L, Dehghan A. Compare the Quality of Life in Type 2 Diabetic Patients with Healthy Individuals (Application of WHOQOLBREF). Zahedan Journal of Research in Medical Sciences. 2017; In Press(In Press), doi: 10.5812/zjrms.5882.

14. Beaton D, Bombardier C, Ferraz MB. Recommendations for the cross-cultural adaptation of the DASH \& QuickDASH outcome measures. Institute for Work \& Health. 2007; 1(1): 1-45.

15. Beaton DE, Bombardier C, Guillemin F, et al. Guidelines for the process of cross-cultural adaptation of self-report measures. Spine (Phila Pa 1976). 2000; 25(24): 3186-3191, doi: 10.1097/00007632200012150-00014, indexed in Pubmed: 11124735.

16. Likert RA. Technique for the measurement of attitudes. Archives of Psychology. 1932; 140: 1-55.

17. Menino E, Dos M, Clarisse M. Validation of Diabetes Knowledge Questionnaire (DKQ) in the Portuguese Population. Diabetes Obes Int J. 2017; 2(1): 1-8.

18. Alarcon LC. Level of knowledge in patients with type 2 diabetes mellitus and its relationship with glycemic levels and stages of Grief according to Kübler-Ross. Journal of Diabetes \& Metabolism. 2015; 06(02), doi: 10.4172/2155-6156.1000495.

19. Gyawali B, Mishra SR, Neupane D, et al. Diabetes management training for female community health volunteers in Western Nepal: an implementation experience. BMC Public Health. 2018; 18(1): 641, doi: 10.1186/s12889-018-5562-y, indexed in Pubmed: 29783961.

20. Rao AR, Sreelakshmi P, Prabhu DD, et al. malayalam questionnaire for the assessment of knowledge regarding diabetes. Kerala Med J. 2016; 9(1): 7-11.

21. Martin S, Schneider B, Heinemann L, et al. Self-monitoring of blood glucose in type 2 diabetes and long-term outcome: an epidemiological cohort study. Diabetologia. 2006; 49(2): 271-278, doi: 10.1007/s00125-005-0083-5, indexed in Pubmed: 16362814.

22. Croatian Health Insurance Fund. https://www.hzzo.hr/zdravstveni-sustav-rh/medicinski-proizvodi/ (18.09.2020).

23. Oba S, Yamamoto M, Horikawa Y, et al. Gifu Diabetes Study Group. Knowledge of diabetes and its determinants: a cross-sectional study among adults in a Japanese community. BMJ Open. 2019; 9(5): e024556, doi: 10.1136/bmjopen-2018-024556, indexed in Pubmed: 31152029.

24. Croatian bureau of statistics. Basic characteristics of household consumption, 2017. https://www.dzs.hr/Hrv_Eng/publication/2018/14-01-02_01_2018.htm (10.05.2020).

25. Mahfouz EM, Kamal NN, Mohammed ES, et al. Effects of mothers' knowledge and coping strategies on the glycemic control of their diabetic children in Egypt. Int J Prev Med. 2018; 9: 26, doi: 10.4103/ijpvm.IJPVM_336_17, indexed in Pubmed: 29619150.

26. Dussa K, Parimalakrishnan S, Sahay R. Assessment of diabetes knowledge using diabetes knowledge questionnaire among people with type 2 diabetes mellitus. Asian J Pharm Clin Res. $2015 ; 8(2): 254-256$

27. Ozcelik F, Yiginer O, Arslan E, et al. Association between glycemic control and the level of knowledge and disease awareness in type 2 diabetic patients. Pol Arch Med Wewn. 2010; 120(10): 399-406, indexed in Pubmed: 20980945.

28. Gholami A, Jahromi LM, Zarei E, et al. Application of WHOQOLBREF in Measuring Quality of Life in Health-Care Staff. Int J Prev Med. 2013; 4(7): 809-817, indexed in Pubmed: 24049600.

29. Mujika-Zabaleta A, Forbes A, While A, et al. Relationship between diabetes knowledge, glycaemic control and quality of life: pilot study. Diabetes Prim Care. 2010; 12: 376-381. 


\section{DKQ Croatian version}

1. Konzumacija velikih količina šećera i druge slatke hrane uzrokuje šećernu bolest.

\begin{tabular}{|c|c|c|}
\hline DA & $\mathrm{NE}$ & NEZNAM \\
\hline DA & $\mathrm{NE}$ & NEZNAM \\
\hline DA & $\mathrm{NE}$ & NEZNAM \\
\hline DA & $\mathrm{NE}$ & NEZNAM \\
\hline DA & $\mathrm{NE}$ & NEZNAM \\
\hline DA & $\mathrm{NE}$ & NEZNAM \\
\hline DA & NE & NEZNAM \\
\hline DA & $\mathrm{NE}$ & NEZNAM \\
\hline DA & $\mathrm{NE}$ & NEZNAM \\
\hline DA & $\mathrm{NE}$ & NEZNAM \\
\hline DA & $\mathrm{NE}$ & NEZNAM \\
\hline DA & NE & NEZNAM \\
\hline DA & NE & NEZNAM \\
\hline DA & NE & NEZNAM \\
\hline DA & NE & NEZNAM \\
\hline DA & NE & NEZNAM \\
\hline DA & NE & NEZNAM \\
\hline DA & $\mathrm{NE}$ & NEZNAM \\
\hline DA & NE & NEZNAM \\
\hline DA & NE & NEZNAM \\
\hline DA & NE & NEZNAM \\
\hline DA & NE & NEZNAM \\
\hline DA & $\mathrm{NE}$ & NEZNAM \\
\hline DA & NE & NEZNAM \\
\hline
\end{tabular}

2. Uobičajeni uzrok šećerne bolesti je smanjeni učinak inzulina u organizmu.

3. Uzrok šećerne bolesti je nemogućnost bubrega da spriječe izlučivanje šećera u urinu.

4. Bubrezi proizvode inzulin.

5. Ako se šećerna bolest ne liječi, količina šećera u krvi raste.

6. Ako sam dijabetičar, moja djeca imaju veći rizik da budu dijabetičari.

7. Šećerna bolest se može izliječiti.

8. Razina šećera u krvi natašte iznad $11 \mathrm{mmol} / \mathrm{L}$ je previsoka.

9. Najbolji način za provođenje samokontrole je analiza urina.

10. Redovita tjelovježba će povećati potrebu tijela za inzulinom ili lijekovima za šećernu bolest.

11. Postoje dva glavna tipa šećerne bolesti: tip 1 (inzulin - ovisan) i tip 2 (inzulin - neovisan).

12. Prejedanje dovodi do inzulinske reakcije (pada šećera u krvi).

13. Lijekovi su puno važniji za dobru kontrolu šećerne bolesti od pravilne prehrane i redovite tjelovježbe.

14. Šećerna bolest često dovodi do loše cirkulacije.

15. Porezotine i ogrebotine sporije cijele kod osoba s šećernom bolesti.

16. Osobe sa šećernom bolesti trebaju biti oprezne prilikom podrezivanja noktiju na stopalima.

17. Osoba sa šećernom bolesti trebala bi očistiti porezotinu jodom i alkoholom.

18. Način pripreme hrane jednako je važan kao i odabir namirnica.

19. Šećerna bolest može oštetiti moje bubrege.

20. Šećerna bolest može dovesti do gubitka osjeta u mojim prstima, šakama i stopalima.

21. Znojenje i tresavica su znakovi visoke razine šećera u krvi.

22. Učestalo mokrenje i žeđ su znakovi niske razine šećera u krvi.

23. Uski elastični zavoji ili čarape nisu štetni za dijabetičare.

DA NE

24. Dijabetička dijeta se uglavnom sastoji od posebnih namirnica. 


\section{APPENDIX 2}

DKQ English version

1. Eating too much sugar and other sweet foods is a cause of diabetes.

YES NO I DON'T KNOW

2. The usual cause of diabetes is lack of effective insulin in the body.

YES NO I DON'T KNOW

3. Diabetes is caused by failure of the kidneys to keep sugar out of the urine.

YES NO I DON'T KNOW

4. Kidneys produce insulin.

5. In untreated diabetes, the amount of sugar in the blood usually increases.

YES NO I DON'T KNOW

6. If I am diabetic, my children have a higher chance of being diabetic.

YES NO I DON'T KNOW

7. Diabetes can be cured.

8. A fasting blood sugar level of 210 is too high.

YES NO I DON'T KNOW

YES NO I DON'T KNOW

YES NO I DON'T KNOW

9. The best way to check my diabetes is by testing my urine.

YES NO I DON'T KNOW

10. Regular exercise will increase the need for insulin or other diabetic medication.

YES NO I DON'T KNOW

11. There are two main types of diabetes: Type 1 (insulin-dependent) and Type 2 (non-insulin-dependent).

12. An insulin reaction is caused by too much food.

13. Medication is more important than diet and exercise to control my diabetes.

14. Diabetes often causes poor circulation.

15. Cuts and abrasions on diabetics heal more slowly.

16. Diabetics should take extra care when cutting their toenails.

17. A person with diabetes should cleanse a cut with iodine and alcohol.

18. The way I prepare my food is as important as the foods I eat.

19. Diabetes can damage my kidneys.

20. Diabetes can cause loss of feeling in my hands, fingers, and feet.

21. Shaking and sweating are signs of high blood sugar.

22. Frequent urination and thirst are signs of low blood sugar.

23. Tight elastic hose or socks are not bad for diabetics.

YES NO I DON'T KNOW

24. A diabetic diet consists mostly of special foods.

YES NO I DON'T KNOW

YES NO I DON'T KNOW

YES NO I DON'T KNOW

YES NO I DON'T KNOW

YES NO I DON'T KNOW

YES NO I DON'T KNOW

YES NO I DON'T KNOW

YES NO I DON'T KNOW

YES NO I DON'T KNOW

YES NO I DON'T KNOW

YES NO I DON'T KNOW

YES NO I DON'T KNOW

YES NO I DON'T KNOW 